\title{
Which is Better in Predicting Mortality in Patients Hospitalized for COVID-19: CURB-65 Score Versus Physicians' Gestalt
}

\section{(1) Sarper Yılmaz, (1) Erdal Yilmaz}

\section{Department of Emergency Medicine, University of Health Sciences, Kartal Dr. Lütfi Kırdar City Hospital, İstanbul, Turkey \\ Submitted: 05.08.2021 Accepted: 06.08.2021 \\ Correspondence: Erdal Yılmaz, SBÜ, Kartal Dr. Lütfi Kırdar Şehir Hastanesi, Acil Tıp Anabilim Dalı, İstanbul, Turkey E-mail: erdalyilmazmd@gmail.com

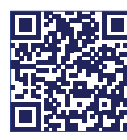 \\ Keywords: COVID-19, CURB-65; gestalt; mortality. \\ This work is licensed under a Creative Common Attribution-NonCommercial 4.0 International License.}

\begin{abstract}
Objective: This study aims to measure and compare the CURB-65 score and the predictive performance of physician's gestalt in predicting mortality for COVID-I9 patients admitted to the emergency department (ED) and intended for hospitalization.
\end{abstract}

Methods: This study was designed as prospective-observational. All COVID-19 patients admitted to the ED between May I and June I, 202I, were included in the study. Based on these results, the gestalt percentages and CURB-65 scores of the hospitalized patients were calculated, and the in-hospital mortality predictive power was analyzed.

Results: This study was performed with $\mathrm{IOI}$ patients after utilising the inclusion-exclusion criteria. The mean age of the patients was $75.9 \pm 9.31$ years and $55(54.5 \%)$ were male. The most suitable cut-off value for CURB-65 was found to be $\geq 2.50$, and the most suitable cutoff value for Gestalt was found to be $\geq 35 \%$. Area under the curve (AUC) value, sensitivity and specificity of CURB-65, was calculated as $0.668,0.500$ and $0.84 \mathrm{I}$, respectively. For Gestalt, these values were found as $0.630,0.789$ and 0.444 , respectively.

Conclusion: In this study, it was revealed that the predictive powers of the CURB-65 score and physician's gestalt were successful in predicting in-hospital mortality for COVID-19 patients, but they were not superior to each other. According to the results of our study, we suggest the use of gestalt for physicians working in limited-resource or crowded EDs.

\section{INTRODUCTION}

Since March II, 2020, the World Health Organization (WHO) has declared the Coronavirus disease 2019 (COVID-19), caused by SARS-CoV-2, as an international pandemic and public health emergency. ${ }^{[1-3]}$ The first recognised case of the COVID-19 pandemic in Turkey, which has spread around the world, was announced by the Ministry of Health on March II. The first death due to the virus occurred on March I5, 2020. ${ }^{[4]}$

Confirmation of COVID-19 relies on microbiological testing such as real-time polymerase chain reaction (RT$P C R) .{ }^{[5,6]}$ However, in the first days of the pandemic, undesirable disruptions were experienced in healthcare services due to the fact that the PCR test could not be done rapidly in every hospital and the test results were late. Therefore, effective triage is essential in disaster situations such as pandemics. For this purpose, the CURB-65 score, which had been previously validated risk predictor in pneumonia patients, was used as a triage score. ${ }^{[7]}$ This score, which is easy to calculate and suitable for effective triage, consists of only 5 parameters (confusion, blood urea nitrogen (BUN), respiratory rate, blood pressure and age) and can be used as an early warning system for patients who are about to die. Although it seems simple, the fact that it includes laboratory parameters limits the use of this score, especially in crowded EDs.So, do physicians working under limited conditions have to wait desperately for laboratory results? In such cases, physicians have another weapon they use reflexively, perhaps unconsciously: Gestalt. Clinical gestalt is the theory of actively organizing the clinical perceptions of healthcare workers (HCWs) into coherent holistic structures. ${ }^{[8]}$ This means that clinicians can implicitly make clinical decisions in the absence of complete information and produce solutions by generalizing and transferring a characterized problem to another. At its core, the clinical gestalt is an intuitive approach to design recognition and decision making.

This study aims to measure and compare the CURB-65 score and the predictive performance of physician's gestalt in predicting mortality for COVID- 19 patients admitted to the ED and intended for hospitalization. 


\section{MATERIALS AND METHODS}

This prospective observational study was carried out in the ED of a tertiary teaching hospital between May I, 202 I and June I, 202I. The institutional review board approved the analysis and issued a consent waiver. All COVID-19 patients admitted to the ED between May I and June I, 202I, were included in the study. Patients with negative RT-PCR test, patients with deficient vital signs, patients transferred from another hospital, patients who were not hospitalized but were given outpatient treatment, patients whose CURB-65 score could not be calculated, and patients who could not be followed were excluded from the study. The following data of all patients included in the study were recorded: vital parameters, laboratory results, comorbidities, RT-PCR results, physical examination findings.

One of the researchers was informed when there was a patient from the ED to be hospitalized for COVID-19. This researcher was informed about the patient's medical history and anamnesis, and after the physical examination and examination of patient's electrocardiogram, the patient was asked to choose one of the following five values for mortality estimation; $0 \%$ to $5 \%, 6 \%$ to $25 \%, 26 \%$ to $50 \%, 51 \%$ to $75 \%$, and $76 \%$ to $100 \%$. These values were saved in a form. After calculating the patients' CURB-65 score, the other researcher performed the statistical analysis to compare it with the numerical gestalt values given by the first researcher. The primary outcome of the study was determined as all-cause in-hospital death.

\section{Statistical analysis}

NCSS (Number Cruncher Statistical System) 2007 (Kaysville, Utah, USA) program was used for statistical analysis. While evaluating the study data, descriptive statistical methods (Mean, Standard Deviation, Median, Frequency, Ratio, Minimum, Maximum) as well as the Mann Whitney $U$ test were used for two-group comparisons of non-normally distributed parameters. Pearson Chi-Square test was used to compare qualitative data. ROC analysis was performed to determine the positivity cut-off value. Significance was evaluated at $p<0.01$ and $p<0.05$ levels.

\section{RESULTS}

This study was completed with 101 patients after applying the inclusion-exclusion criteria. The mean age of the patients was $75.9 \pm 9.31$ years and 55 (54.5\%) were male (Table I). According to mortality status, CAD (Coronary Artery Disease), AF (Atrial Fibrillation), CRF (Chronic Kidney Failure), Consciousness Impairment, Dyspnea (shortness of breath) and Thorax Tomography finding result distributions do not show a statistically significant difference $(p>0.05)$. However, the incidence of CHF (heart failure) differs statistically significance $(p=0.017 ; p<0.05)$. Its incidence was found to be higher in mortal patients (Table 2).
Table I. General characteristics of the patients

\begin{tabular}{|c|c|c|c|}
\hline & & $\mathbf{n}$ & $\%$ \\
\hline \multirow[t]{2}{*}{ Sex } & Female & 46 & 45.5 \\
\hline & Male & 55 & 54.5 \\
\hline \multirow[t]{2}{*}{ COPD } & No & 63 & 62.4 \\
\hline & Yes & 38 & 37.6 \\
\hline \multirow[t]{2}{*}{ DM } & No & 46 & 45.5 \\
\hline & No & 55 & 54.5 \\
\hline \multirow[t]{2}{*}{ HT } & No & 87 & 86.1 \\
\hline & Yes & 14 & 13.9 \\
\hline \multirow[t]{2}{*}{$\mathrm{CHF}$} & No & 79 & 78.2 \\
\hline & Yes & 22 & 21.8 \\
\hline \multirow[t]{2}{*}{ CAD } & No & 95 & 94.1 \\
\hline & Yes & 6 & 5.9 \\
\hline \multirow[t]{2}{*}{ AF } & No & 90 & 89.1 \\
\hline & Yes & 11 & 10.9 \\
\hline \multirow[t]{2}{*}{ CKD } & No & 49 & 48.5 \\
\hline & Yes & 52 & 51.5 \\
\hline \multirow[t]{2}{*}{ Alzheimer's, dementia } & No & 22 & 21.8 \\
\hline & Yes & 79 & 78.2 \\
\hline Consciousness & No & 13 & 12.9 \\
\hline disorder & Yes & 88 & 87. 1 \\
\hline Dyspnea (shortness & No & 8 & 7.9 \\
\hline of breath) & Yes & 28 & 27.7 \\
\hline Chest tomography & No & 65 & 64.4 \\
\hline finding & Covid compatible & 66 & 65.3 \\
\hline \multirow[t]{3}{*}{ GESTALT } & $26-50 \%$ & 35 & 34.7 \\
\hline & $51-75 \%$ & 63 & 62.4 \\
\hline & $76-100 \%$ & 38 & 37.6 \\
\hline \multirow[t]{2}{*}{ Hospitalization status } & Hospital service & 3 & 3.0 \\
\hline & Intensive care & 69 & 68.3 \\
\hline \multirow[t]{2}{*}{ Mortality } & Non-survivor & 26 & 25.7 \\
\hline & Survivor & 3 & 3.0 \\
\hline \multirow[t]{5}{*}{ CURB-65 Score } & 1.00 & 46 & 45.5 \\
\hline & 2.00 & 55 & 54.5 \\
\hline & 3.00 & 63 & 62.4 \\
\hline & 4.00 & 38 & 37.6 \\
\hline & Mean $\pm S D$ & \multicolumn{2}{|c|}{$\begin{array}{l}\text { Min-Max } \\
\text { (Median) }\end{array}$} \\
\hline Age & $75.9 \pm 9.31$ & \multicolumn{2}{|c|}{$46-100.8(74.57)$} \\
\hline Systolic blood pressure & $122.29 \pm 18.92$ & \multicolumn{2}{|c|}{$60-180(120)$} \\
\hline Diastolic blood pressure & $72.81 \pm 12$ & \multicolumn{2}{|c|}{$20-109(70)$} \\
\hline Pulse & $85.33 \pm 16.44$ & \multicolumn{2}{|c|}{$58-160(84)$} \\
\hline $\mathrm{spO}_{2}$ & $90.28 \pm 9.61$ & \multicolumn{2}{|c|}{$50-100(94)$} \\
\hline Fever & $36.83 \pm 0.68$ & \multicolumn{2}{|c|}{$35.9-39.2(36.7)$} \\
\hline Respiration rate & $24.61 \pm 7.22$ & \multicolumn{2}{|c|}{$14-45(22)$} \\
\hline Urea & $59.31 \pm 53.44$ & \multicolumn{2}{|c|}{$13-402(43.5)$} \\
\hline GCS & $|4.46 \pm 1.9|$ & \multicolumn{2}{|c|}{$6-15(15)$} \\
\hline
\end{tabular}

COPD: Chronic obstructive pulmonary disease; DM: Diabetes mellitus; $\mathrm{HT}$ : Hypertension; CHF: Congestive heart failure; CAD: Coronary artery disease; AF: Atrial fibrillation; CKD: Chronic kidney failure; GCS: Glasgow Coma Scale; SD: Standard deviaiton. 
Table 2. Evaluation of demographic characteristics and measurements by mortality

\begin{tabular}{|c|c|c|c|c|c|c|}
\hline & & \multicolumn{2}{|c|}{ Survivor } & \multicolumn{2}{|c|}{ Non-survivor } & \multirow[t]{2}{*}{$\mathbf{p}$} \\
\hline & & $\mathbf{n}$ & $\%$ & $\mathbf{n}$ & $\%$ & \\
\hline \multirow[t]{2}{*}{ Sex } & Female & 28 & 44.4 & 18 & 47.4 & \multirow[t]{2}{*}{${ }^{\mathrm{a}} 0.775$} \\
\hline & Male & 35 & 55.6 & 20 & 52.6 & \\
\hline Chronic obstructive & No & 54 & 85.7 & 30 & 78.9 & ${ }^{\mathrm{a}} 0.115$ \\
\hline pulmonary disease & Yes & 9 & 14.3 & 8 & 21.1 & \\
\hline \multirow[t]{2}{*}{ Diabetes mellitus } & No & 37 & 58.7 & 26 & 68.4 & \multirow[t]{2}{*}{${ }^{\mathrm{a}} 0.330$} \\
\hline & Yes & 26 & 41.3 & 12 & 31.6 & \\
\hline \multirow[t]{2}{*}{ Hypertension } & No & 28 & 44.4 & 18 & 47.4 & \multirow[t]{2}{*}{${ }^{\mathrm{a}} 0.775$} \\
\hline & Yes & 35 & 55.6 & 20 & 52.6 & \\
\hline \multirow[t]{2}{*}{ Congestive heart failure } & No & 58 & 92.1 & 29 & 76.3 & \multirow[t]{2}{*}{${ }^{\mathrm{a}} 0.027^{*}$} \\
\hline & Yes & 5 & 7.9 & 9 & 23.7 & \\
\hline \multirow[t]{2}{*}{ Coronary artery disease } & No & 48 & 76.2 & 31 & 81.6 & \multirow[t]{2}{*}{${ }^{\mathrm{a}} 0.525$} \\
\hline & Yes & 15 & 23.8 & 7 & 18.4 & \\
\hline \multirow[t]{2}{*}{ Atrial fibrillation } & No & 59 & 93.7 & 36 & 94.7 & \multirow[t]{2}{*}{${ }^{\mathrm{a}} 0.823$} \\
\hline & Yes & 4 & 6.3 & 2 & 5.3 & \\
\hline \multirow[t]{2}{*}{ Chronic kidney failure } & No & 58 & 92.1 & 32 & 84.2 & \multirow[t]{2}{*}{${ }^{\mathrm{a}} 0.220$} \\
\hline & Yes & 5 & 7.9 & 6 & 15.8 & \\
\hline \multirow[t]{2}{*}{ Alzheimer's, dementia } & No & 23 & 36.5 & 26 & 68.4 & \multirow[t]{2}{*}{${ }^{\mathrm{a}} 0.00 I^{*}$} \\
\hline & Yes & 40 & 63.5 & 12 & 31.6 & \\
\hline \multirow[t]{2}{*}{ Consciousness Disorder } & No & 62 & 98.4 & 35 & 92.1 & \multirow[t]{2}{*}{${ }^{\mathrm{a}} 0.379$} \\
\hline & Yes & 1 & 1.6 & 3 & 7.9 & \\
\hline \multirow[t]{2}{*}{ Dyspnea (shortness of breath) } & No & 13 & 20.6 & 9 & 23.7 & \multirow[t]{2}{*}{${ }^{\mathrm{a}} 0.719$} \\
\hline & Yes & 50 & 79.4 & 29 & 76.3 & \\
\hline \multirow[t]{2}{*}{ Chest tomography finding } & No & 9 & 14.3 & 4 & 10.5 & \multirow[t]{2}{*}{${ }^{\mathrm{a}} 0.585$} \\
\hline & Covid compatible & 54 & 85.7 & 34 & 89.5 & \\
\hline \multirow[t]{3}{*}{ Hospitalization status } & Hospital service & 57 & 90.5 & 9 & 23.7 & \multirow[t]{2}{*}{${ }^{\mathrm{a}} 0.00 \mathrm{I}^{*}$} \\
\hline & Intensive care & 6 & 9.5 & 29 & 76.3 & \\
\hline & & Mea & edian) & Mear & ledian) & $\mathbf{p}$ \\
\hline Age & & & (73) & $77 . \varepsilon$ & (78.5) & '0.079 \\
\hline Systolic blood pressure & & 122 & $(120)$ & 122 & $4(120)$ & b0.932 \\
\hline Diastolic blood pressure & & 73. & & 71. & (70) & ${ }^{\mathrm{b}} 0.174$ \\
\hline Pulse & & 83. & $(82)$ & 89. & $2(88)$ & '0.234 \\
\hline $\mathrm{spO}_{2}$ & & & (95) & 84. & (86) & ${ }^{b} 0.001^{* *}$ \\
\hline Fever & & & 36.7) & & $(37)$ & ${ }^{\mathrm{b}} 0.239$ \\
\hline Respiration rate & & & (22) & & 29) & ${ }^{b} 0.001^{* *}$ \\
\hline Urea & & 46. & $3(40)$ & 80. & $3(53)$ & ${ }^{b} 0.004^{* *}$ \\
\hline Glasgow Coma Scale & & & (15) & 14 & $(15)$ & ${ }^{\mathrm{b}} 0.246$ \\
\hline
\end{tabular}

aPearson Chi-Square; 'Mann-Whitney U Testi; *p<0.05; ${ }^{* *} p<0.0$ I. SD: Standard deviation.

Gestalt percentages show statistical differences according to mortality status $(p=0.001 ; p<0.01)$. Its prevalence was found to be higher between $76-100 \%$ in mortal patients (Table 3). CURB-65 score shows statistical significance according to mortality status $(p=0.004 ; p<0.01)$. The score 2 rate in discharged patients and the score $2-3$ rate in mortal patients were found to be higher (Table 3).

The cut-off sensitivity and specificity values are calculated for the positivity limit. The value with the highest specificity ratio is determined as the cut-off value. The area gives the value of the area under the curve. This value is expect- ed to be greater than 0.6 and 0.6 (8). The optimal cut-off value for CURB-65 is $\geq 2.50$. The optimal cut-off value for Gestalt is $\geq 35 \%$. The AUC value, sensitivity and specificity of CURB-65, were calculated as $0.668,0.500$ and $0.84 I$, respectively. For Gestalt, these values were found to be $0.630,0.789$ and 0.444 , respectively.

\section{DISCUSSION}

In this study, the performance of CURB-65 and doctors' gestalt in predicting mortality in ED and hospitalized patients was compared, and it was concluded that both pre- 
dictors were effective in predicting mortality, but were not superior to each other.

Gestalt is a theory in the sense of 'the attitude and functioning of the meaningful whole formed by the designed parts'. There are also some abbreviations as 'form of meaning'. Gestalt psychologists studied the functions of the brain based on its ability to organize form and design to understand how the brain regulates sensory stimuli and the human perception process. Gestalt laboratories created amazing patterns based on geometry. Thanks to these studies, some of which are examples of visual illusions, it was revealed that the brain has the ability to naturally regulate visual stimuli. Moving and changing direction causes the image on the retina to change. However, objects are perceived with their actual size, colour and shape. Instead of seeing our world as reflected on the retina, we organize reality with our visual memory, and comprehend it through reconstruction. ${ }^{[9-11]}$ Clinical gestalt is the clinician's evaluation of the patient's clinic, thoughts about the patient, and patient-oriented opinions during the treatment process. At the beginning of the $20^{\text {th }}$ century, a group of German scientists working in the field of art psychology suggested that "form is the most basic unit of art perception", and the concept of Gestalt was accepted as a turning point in both art and psychology.. After the Nazi influence in Germany and the banning of the journal they published in the field of psychology, a group of scientists who immigrated to America continued their publications while giving lectures on perception at universities. $^{[8]}$ These publications contributed to the develop-

Table 3. Evaluation of GESTALT and CURB-65 Scores by mortality

\begin{tabular}{|c|c|c|c|c|c|}
\hline & \multicolumn{2}{|c|}{ Survivor } & \multicolumn{2}{|c|}{ Non-survivor } & \multirow[t]{2}{*}{$\mathbf{p}$} \\
\hline & $n$ & $\%$ & $n$ & $\%$ & \\
\hline \multicolumn{6}{|l|}{ GESTALT } \\
\hline $26-50 \%$ & 8 & 12.7 & 0 & 0.0 & ${ }^{\mathrm{a}} 0.001$ \\
\hline $5 I-75 \%$ & 20 & 31.7 & 8 & 21.1 & \\
\hline $76-100 \%$ & 35 & 55.6 & 30 & 78.9 & \\
\hline \multicolumn{6}{|c|}{ CURB-65 Score } \\
\hline 1.00 & 2 & 3.2 & I & 2.6 & ${ }^{\mathrm{a}} 0.004$ \\
\hline 2.00 & 51 & 81.0 & 18 & 47.4 & \\
\hline 3.00 & 9 & 14.3 & 17 & 44.7 & \\
\hline 4.00 & 1 & 1.6 & 2 & 5.3 & \\
\hline
\end{tabular}

ment of Gestalt theory and even the current pandemic has been the subject of studies. Nazarian et al reported that in 193 suspected COVID-19 patients admitted to the $E D$, the physician's use of gestalt in addition to imaging methods was quite successful with a diagnostic power of 0.808 AUC. $^{\left[{ }^{12]}\right.}$ In another study, several mortality scores (LOW-HARM, qSOFA, MSL-COVID-19, NUTRI-CoV and NEWS2) were compared according to physician's gestalt, and no score was found to be superior to the physician's gestalt. ${ }^{[13]}$ In this study, physicians were found to be as successful as gestalt, and the CURB-65 score that every emergency medicine physician is familiar with consists of only five parameters that can be easily obtained (mainly obtained from vital signs). This has been confirmed in different populations and has been acknowledged as a strong predictor of mortality in pneumonia patients. ${ }^{[14-16]}$ Seller et al published that the CURB-65 score is more successful than PSI (pneumonia severity index) in determining the 30-day mortality of hospitalized COVID- 19 patients. ${ }^{[17]}$ Jun Guo et al in their study reported that the CURB-65 score was quite successful with an AUC of $0.8 \mathrm{I}$ in predicting the in-hospital mortality of COVID-19 patients. ${ }^{[7]}$ Our study has some limitations. The outcomes of a study conducted from a single centre and in a relatively small population cannot be generalized to the entire population. If the laboratory and imaging results of the patients are added to our gestalt model created by the physician only with the physical examination findings and the patient's anamnesis, more successful outcomes can be achieved.

\section{CONCLUSION}

In this study, it was determined that the predictive powers of the CURB-65 score and physician's gestalt were successful in predicting in-hospital mortality for COVID-19 patients, but were not superior to each other. According to the outcome of our study, we recommend the use of gestalt to physicians working in limited resources or crowded EDs.

\section{Ethics Committee Approval}

This study approved by the Kartal Dr. Lutfi Kirdar City Hospital Clinical Research Ethics Committee (Date: 28.04.202 I, Decision No: 202 I/5 I4/200/30).

Informed Consent

Prospective study.

Peer-review

Internally peer-reviewed.

Table 4. ROC analysis results by mortality

\begin{tabular}{|c|c|c|c|c|c|c|}
\hline & \multirow[t]{2}{*}{ Cut off value } & \multirow[t]{2}{*}{ Area (AUC) } & \multirow[t]{2}{*}{ Sensitivity } & \multirow[t]{2}{*}{ Specificity } & \multicolumn{2}{|c|}{$95 \%$ Confidence interval } \\
\hline & & & & & Lower & Upper \\
\hline CURB-65 Score & $\geq 2.50$ & 0.668 & 0.500 & 0.841 & 0.554 & 0.782 \\
\hline Gestalt & $\geq 35 \%$ & 0.630 & 0.789 & 0.444 & 0.522 & 0.738 \\
\hline
\end{tabular}




\section{Authorship Contributions}

Concept: S.Y., E.Y.; Design: S.Y., E.Y.; Supervision: S.Y., E.Y.; Fundings: S.Y., E.Y.; Materials: S.Y., E.Y.; Data: S.Y., E.Y.; Analysis: S.Y., E.Y.; Literature search: S.Y., E.Y.; Writing: S.Y., E.Y.; Critical revision: S.Y., E.Y.

Conflict of Interest

None declared.

\section{REFERENCES}

1. Doğanay F, Elkonca F, Seyhan AU, Y1lmaz E, Batırel A, Ak R. Shock index as a predictor of mortality among the Covid-19 patients. Am J Emerg Med 2021;40:106-9. [CrossRef]

2. Seyhan AU, Doganay F, Yilmaz E, Topal NP, Ak R. Investigation of QT prolongation with hydroxychloroquine and azithromycin for the treatment of COVID-19. J Coll Physicians Surg Pak 2020;30:1537. [CrossRef]

3. Ak R, Kurt E, Bahadirli S. The comparison of two risk prediction models specific for COVID-19: The Brescia-COVID Respiratory Severity Scale versus the Quick COVID-19 Severity Index. Disaster Med Public Health Prep 2021:1-17. [CrossRef]

4. Seyhan AU, Doğanay F, Yılmaz E, Aydıner Ö, Ak R, Demir Tekol S. The comparison of chest CT and RT-PCR during the diagnosis of COVID-19. J Clin Med Kaz 2021;18:53-6. [CrossRef]

5. Corman VM, Landt O, Kaiser M, Molenkamp R, Meijer A, Chu DK, et al. Detection of 2019 novel coronavirus $(2019-\mathrm{nCoV})$ by real-time RT-PCR. Euro Surveill 2020;25:2000045. [CrossRef]

6. Çelik İA, Cınar E, Karaoğlanoğlu N. Thoracic surgery during Covid-19 pandemic; Single center experience. Acta Medica 2020;51:32-7. [CrossRef]

7. Guo J, Zhou B, Zhu M, Yuan Y, Wang Q, Zhou H, et al. CURB65 may serve as a useful prognostic marker in COVID-19 patients within Wuhan, China: a retrospective cohort study. Epidemiol Infect 2020;148:e241. [CrossRef]
8. Cook C. Is clinical gestalt good enough? J Man Manip Ther 2009;17:6-7. [CrossRef]

9. Tomak L, Bek Y. The analysis of receiver operating characteristic curve and comparison of the areas under the curve. Journal of Experimental and Clinical Medicine 2011;27:58-65. [CrossRef]

10. Dale AP, Marchello C, Ebell MH. Clinical gestalt to diagnose pneumonia, sinusitis, and pharyngitis: a meta-analysis. Br J Gen Pract 2019;69:e444-53. [CrossRef]

11. Sena MCC, Teles KS, Belmino MC. The contribution of gestalt-therapy in violence against women in pandemic times of COVID-19. Revista Interfaces: Saúde, Humanas e Tecnologia 2020;8:675-83.

12. Nazerian P, Morello F, Prota A, Betti L, Lupia E, Apruzzese L, et al; ED COVID-19 Investigators. Diagnostic accuracy of physician's gestalt in suspected COVID-19: Prospective bicentric study. Acad Emerg Med 2021;28:404-11. [CrossRef]

13. Soto-Mota A, Marfil-Garza BA, de Obeso SC, Martínez E, Carrillo-Vázquez DA, Tadeo-Espinoza $\mathrm{H}$, et al. Prospective predictive performance comparison between Clinical Gestalt and validated COVID-19 mortality scores. medRxiv Apr 18, 2021, doi: https:// doi.org/10.1101/2021.04.16.21255647. [CrossRef]

14. Lim WS, van der Eerden MM, Laing R, Boersma WG, Karalus N, Town GI, et al. Defining community acquired pneumonia severity on presentation to hospital: an international derivation and validation study. Thorax 2003;58:377-82. [CrossRef]

15. Capelastegui A, España PP, Quintana JM, Areitio I, Gorordo I, Egurrola $\mathrm{M}$, et al. Validation of a predictive rule for the management of community-acquired pneumonia. Eur Respir J 2006;27:151-7. [CrossRef]

16. Aujesky D, Auble TE, Yealy DM, Stone RA, Obrosky DS, Meehan TP, et al. Prospective comparison of three validated prediction rules for prognosis in community-acquired pneumonia. Am J Med 2005;118:384-92. [CrossRef]

17. Satici C, Demirkol MA, Sargin Altunok E, Gursoy B, Alkan M, Kamat $\mathrm{S}$, et al. Performance of pneumonia severity index and CURB-65 in predicting 30-day mortality in patients with COVID-19. Int J Infect Dis 2020;98:84-9. [CrossRef]

\section{COVID-19 Nedeniyle Hastaneye Yatan Hastaların Mortalite Tahmininde Hangisi Daha İyi: CURB-65 Skoruna Karşı Hekimlerin Gestaltı}

Amaç: Bu çalışmadaki amacımız; acil servise başvurup hastaneye yatışı planlanan COVID-19 hastalarının mortalite tahmininde CURB-65 skoru ve hekimlerin geştalıının prediktif performansını ölçmek ve birbirleriyle karşılaştırmaktır.

Gereç ve Yöntem: Bu çalışma ileriye yönelik-gözlemsel olarak tasarlanmıştır. I Mayıs-I Haziran 202 I tarihleri arasında acil servise başvuran tüm COVID-19 hastaları çalışmaya dahil edilmiştir. Hastaneye yatışı yapılan hastaların gestalt yüzdeleri ve CURB-65 skorları hesaplanmış, bu sonuçlara göre hastane içi mortalite tahmin güçlerinin analizi yapılmışıtır.

Bulgular: Bu çalışma dahil etme-dışlama kriterleri uygulandıktan sonra I0I hasta ile tamamlanmıştır. Hastaların yaş ortalamas $75.9 \pm 9.31$ olup 55'i erkek (\%54.5) idi. CURB-65 için en uygun pozitiflik sınır değeri (cut off) $\geq 2.50$, Gestalt için en uygun pozitiflik sınır değeri (cut off) $\geq \% 35$ olarak bulundu. CURB- 65 'in AUC (area under curve) değeri, sensitivitesi ve spesifitesi sırasıyla; $0.668,0.500$ ve 0.84 I olarak hesapland. Gestalt için ise bu değerler sırasıyla; $0.630,0.789$ ve 0.444 olarak bulundu.

Sonuç: Bu çalışmada COVID-19 hastalarında hastane içi mortaliteyi öngörmede CURB-65 skoru ve hekim gestaltının prediktif güçlerinin başarılı olduğu, ancak birbirlerine üstünlükleri olmadıkları bulunmuştur. Çalışmamızın sonuçlarına göre sınırlı kaynak veya kalabalık acil servislerde çalışan hekimler için gestalt kullanımın öneriyoruz.

Anahtar Sözcükler: COVID-19; CURB-65; gestalt; mortalite. 